\title{
Harm Reduction at its Best: A case for Promoting Safe Injection Facilities
}

\author{
Emilie Meyers, $\mathrm{BScH}^{1}$, Ellen Snyder, $\mathrm{BAH}, \mathrm{BScH}^{1}$
}

${ }^{1}$ Faculty of Medicine, University of Ottawa

A B STRACT

Injection Drug Users (IDU) represent less than 1\% of Canada's total population. Nevertheless, they bare a disproportionate burden of disease with health and law enforcement costs for controlling the drug problem in Canada estimated at \$5 billion annually. The current strategies targeting IDU have limited efficacy in reducing emergency department visits, limiting Human Immunodeficiency Virus (HIV) and Hepatitis C Virus (HCV) transmission and providing accessible health care. This paper makes the case for safe injection facilities (SIF) as a means to improve IDU health outcomes, while reducing health care expenditures, and decreasing public injecting without increasing crime rates. This topic is of particular concern now that the Conservative government is in the process of trying to pass bill C- 2 to modify the Controlled Drugs and Substances Act, making exemptions for SIF inaccessible. This is occurring while leading researchers in the field are applying for an exemption for such a facility in Ottawa.

\section{RÉ S U MÉ}

Les utilisateurs de drogues injectables représentent moins de $1 \%$ de la population globale du Canada. Ils sont néanmoins responsables d'une part disproportionnée du fardeau de la maladie. II est estimé que les coûts des soins de santé et d’application de la loi pour la maîtrise du problème de toxicomanie s'élèvent à 5 milliards de dollars au Canada. Les stratégies actuellement utilisées auprès des utilisateurs de drogues injectables ne réussissent pas à réduire le nombre de visites dans les services d'urgence, à limiter la transmission du virus de l'immunodéficience humaine (VIH) et de l'hépatite $C$ (VHC) ni à fournir des soins de santé adéquats. Cet article établit le bien-fondé des sites d'injection supervisés (SIS) comme moyen d'améliorer les résultats sur la santé des toxicomanes tout en réduisant les dépenses en soins de santé, les injections de drogue dans des lieux publics, et ce, sans hausser le taux de criminalité. Ce sujet est particulièrement d'actualité, car le gouvernement conservateur est en voie de faire adopter le projet de loi C-2 qui modifiera la Loi réglementant certaines drogues et autres substances, rendant inaccessibles les exceptions qui permettent la création de sites d'injection supervisés. Cela se produit au moment même où des chercheurs de pointe dans le domaine sont en voie de déposer une demande pour la création d'un SIS à Ottawa.

Over the last century, there has been a paradigm shift in the way society manages the health of injection drug users, moving public health strategies from an abstinence model to a harm reduction model. Despite the large body of literature supporting their efficacy, the implementation of harm reduction strategies such as needle exchange programs and safe injection fa-cilities continue to encounter significant resistance. Safe injection facilities (SIFs) are the most recent addition to the Canadian harm reduction landscape and are by far the most controversial. The evidence that has emerged following the opening of Canada's first SIF, Insite in Vancouver, BC, has attested to its economic viability, its reduction of the burden of disease, and its positive impact on public safety [1]. This topic is of particular concern at the moment because the current Conservative government is in the process of passing bill C-2 to modify the laws surrounding the Controlled Drugs and Substances Act [2]. This will create insurmountable barriers for the attainment of the legal exemption for the use of controlled substances necessary for the operation of SIFs. Given that harm reduction strategies have an important im-

Keywords: safe injection facilities, harm reduction pact on public health, it is important for the medical community to stay up to date on these political and legal changes in order to advocate for measures that improve the health of all Canadians and reduce the burden on our healthcare system. The current patchwork system of harm reduction efforts has not done enough to curb the financial and human health impacts of injection drug use and it is essential to implement a comprehensive harm reduction strategy to have any noticeable impact. There is compelling evidence from around the world that SIFs should be part of that strategy, and could make a positive impact here in Ottawa.

Although the IDU population in Canada is small, representing less than $1 \%$ of the total population, it bares a disproportionate burden of disease [3]. Many complications can arise from injection drug use such as, HIV, HCV, abscesses, cellulitis, overdoses resulting in hospitalization or death, accidental injury while under the influence, drug addiction, and withdrawal [4]. In addition to these increased health risks, IDUs often face barriers to accessing primary healthcare services due to stigma, discrimination, lack of financial resources, lack of transportation, and an unstable lifestyle that makes it difficult to keep appointments [5, 
6]. Due to these challenges, the IDU population incurs significant healthcare costs through frequent emergency department visits, costly acute care, and inadequate treatment of chronic illnesses [7]. Palepu et al. found that in a sample of 440 IDUs, 2763 visits were made to the emergency department over the three year study period [8]. The provision of inpatient care for this population is also substantial with approximately $15 \%$ of admissions in one Vancouver based hospital attributed to injection drug use [9]. Injection drug use is considered a major risk factor for transmission of HIV, and it also leads to worst health outcomes for those living with the infection [10]. A 2011, survey of new diagnoses of HIV in the United States showed that of the $24.9 \%$ found to have stage 3 disease (AIDS) at the time of diagnosis, 39.2\% were IDUs [11]. Studies have also shown that IDUs are far more likely than their non drug using counterparts to be lost to follow-up and not receive adequate outpatient care after an HIV diagnosis [12]. With the continued existence of infectious disease transmission through needle sharing, and the rates of overdose rising rapidly according to data from Office of the Chief Coroner of Ontario (there is 1 overdose a day in Ottawa alone and a 240\% increase in oxycodone-related death between 2002 and 2006 across the province), much more needs to be done to limit these negative impacts and address the healthcare needs of this population [13, 14].

Harm reduction strategies seek to minimize the harmful consequences of drug use while recognizing that abstinence is not always possible in the short term. Different strategies may target drug users at different stages of their addiction, with the hope that continued engagement with the healthcare system may encourage a progression towards a level of stability that could allow abstinence to be maintained. While current harm reduction strategies, including law enforcement, needle exchange programs, rehabilitation and treatment programs, are a positive first step, more comprehensive strategies need to be explored to better address the problems associated with IDUs. Traditionally, politicians respond to public health crises related to drug use by allocating resources primarily to law enforcement based initiatives [9]. Data from Vancouver showed no changes in crime rates, addiction or infectious disease incidence, when $82 \%$ of the drug related budget was allocated to law enforcement, suggesting that this is not an effective strategy [9]. On the other hand, drug treatment services such as methadone clinics, are a highly effective way to combat the harm of drugs and significantly reduce HIV risk behaviours [15]. Their impact is, however, limited by the fact that they retain only one third of patients [16]. Needle exchange programs can help address this gap by reducing needle sharing among IDUs who are not ready to engage in treatment, and their effectiveness is supported by extensive evidence. However, ongoing problems with HIV and HCV infections in cities where these programs are widely available indicates that needle exchange programs alone are not sufficient to address diseases transmission [9]. Moreover, they do not address other harms associated with drug use such as overdose, injury, and public nuisance. Each of these strategies has its role to play in reducing the negative impacts of drug use and improving health outcomes. However, in order to stop the transmission of HIV and HCV, address overdose rates, and improve the health of those unable to commit to a methadone treatment program, a more accessible and comprehensive strategy must be put in place.

Conclusive evidence has emerged around the world in support of safe injection facilities (SIF). Though this approach remains controversial, it seems to be the most effective way of targeting high risk drug users while reducing the health and financial burden of drug addiction. SIFs provide IDUs with a safe location to inject illicit drugs using sterile supplies, with nurses on site to intervene in the event of an overdose or injury. Nurses can also provide primary care services and addiction treatment referrals [1]. A study published by Andresen and Boyd using mathematical models to estimate the number of prevented HIV infections following the establishment of the Insite SIF in Vancouver in 2003, estimated that 19 to 57 infections are prevented per year [17]. Pinkerton estimates that if Insite were closed, the annual rate of HIV infections would increase by 83.5 cases which would be associated with $\$ 17.6$ million in lifetime HIV-related medical costs, greatly exceeding Insite's operating costs of approximately $\$ 3$ million per year [18]. It should be noted that these cost savings estimates do not account for savings associ-ated with a reduction in HCV infections, which are also common among IDUs. SIF users report reduced needle sharing, which reduces blood born infection transmission [1]. This corroborates with findings from European facilities that report the improvement of general health and social functioning of clients, as well as a reduction in blood born virus transmission risk behaviours [19]. Studies in Europe report a behaviour shift from public drug use to using injecting facilities, thereby decreasing the visibility of drug use significantly and leading to public safety improvements [19]. In Australia, the number of publicly discarded needles in the surrounding area dropped by half when a safe injection facility was opened in Sydney in 2001 [20]. Canadian evidence also shows reduced overdose mortality, with the rate of overdose in proximity to Vancouver's Insite facility decreasing by $35 \%$ after the site was opened [21]. These results indicate a concrete reduction of harm and health care costs as a result the implementation of SIFs. Therefore, SIFs can contribute greatly to the reduction in drug related harms and should be integrated with existing harm reduction services in cities with significant drug problems.

A comprehensive SIF in the Ottawa region could effectively target the needs of IDUs while reducing overdose rates, infectious disease transmission, and total healthcare costs. Although the polished government buildings in Ottawa's downtown could lead one to believe otherwise, Ottawa's drug problem is far from negligible. There were an estimated $1200-5600$ injection drug users in Ottawa in 2008 and, in 2011, 7.7\% of the adult population of Ottawa was estimated to have used crack or cocaine in their lifetime [22]. Drug overdose accounts for 115 hospitalizations and 40 deaths annually in Ottawa [22]. Although the rates of HIV infection among drug users in Ottawa has remained relatively stable around $9.5 \%$ during the period between 
2006 and 2012, HCV prevalence has increased to $70.5 \%$ of drug users in Ottawa in 2012 [22]. Meanwhile the sharing of injection and inhalation equipment remains an important public health issue with $14 \%$ and $60 \%$ of drug users reporting having used another person's injection or inhalation equipment respectively within the last 6 months [22]. Both doctors and policy makers should be paying attention to this situation and looking for ways to address the gaps in the programs currently offered to drug users in Ottawa.

Safe injection sites could be the critical element needed to complete Ottawa's continuum of harm reduction services. Since they target drug users who are homeless, public injectors and at high risk for overdose, SIFs could effectively lower overdose rates and reduce equipment sharing among drug users in Ottawa, where other programs have fallen short [1]. The most effective way to address this problem in Ottawa could be by strategically choosing a high consumption area and installing a standalone safe injection facility run by public health. Jozagihi et al. used mathematic models to evaluate the potential cost effectiveness of an SIF in Ottawa, given its rates of HIV, HCV and estimated equipment sharing. They concluded that " serious consideration should be given to the establishment of SIFs in Ottawa " and that the evidence supported opening two such sites [23]. The literature shows that these types of facilities are also associated with high rates of satisfaction among drug users, which in turn increases the usage of primary health care services within the facility to treat wounds and potential complications, therefore reducing potential hospital admissions [1]. Gaining the trust of this population would allow the SIF in Ottawa to offer many other services such as safer injection education, wound care, and referrals to community resources such as treatment and housing services, as has been done in other jurisdictions $[1,20]$. Not only does this improve the quality of life for the users, but it also supports the ultimate goal of abstinence. Studies evaluating other SIFs, show that more than $40 \%$ of referrals are for various forms of addiction treatment [1]. Supplementary to the sterile and safe environment to inject, the presence of medical personnel, such as nurses and addiction counsellors, offers a comprehensive intervention. Such services have an impact on reducing rates of HIV and HCV infections, overdose mortality and hospital utilization, while increasing referrals to addiction treatment centres. Furthermore, although the public often cites concerns of increased crime rates as a reason not to support establishing such facilities in their neighbourhoods, SIFs have proven to decrease measures of public disorder, and have no other influence on crime rates [1].

The population of IDUs may be relatively small, but it bares a disproportionate burden of disease. With the right intervention strategies, this population could benefit from an improved quality of life, which in turn would reduce the burden on our health care system. The literature demonstrates that individually, many harm reduction and treatment strategies can be effective. However, they fail to reach the most vulnerable population of drug users and therefore alone do not completely solve the problem. Currently the intervention which proves to be the most effective for those most at risk is safe injection facilities. SIFs have seen extensive success in reducing needle sharing and overdose mortality, while increasing drug treatment referrals, and having no impact on overall crime rates. Considered together, the evidence shows that in major metropolitan areas with significant drug problems, such as Ottawa, comprehensive safe injection sites should be opened. The next challenge is getting the support of citizens and politicians.

\section{REFERENCES}

1. Wood E, Tyndall MW, Montaner JS, Kerr T. Summary of findings from the evaluation of a pilot medically supervised injecting facility. Canadian Medical Association Journal. 2006;175(11):1399-1404.

2. Government of Canada. Controlled Drugs and Substance Act [Internet]. Justice Laws Website; 1996. [updated 2014 Jul 02; cited 2014 Mar 30]. Available from: http://laws-lois.justice.gc.ca/eng/acts/C-38.8/page-22. html\#docCont.

3. Begin P, Weekes J, Thomas G. The Canadian addiction survey : Substance use and misuse among the Canadian population. Canadian Forum on Corrections Research. 2006;18:12-18. Available from: http://205.193.117.157/ text/pblct/forum/e181/e181d e.pdf

4. Chitwood DD, McBride DC, French MT, Comeford M. Healthcare need utilization: A prelim-inary comparison of injection drug users, other illicit drug users and nonusers. Substance use \& misuse. 1999;35(4-5):727-746.

5. Drumm R, McBride D, Mesch L, Page J, Dickerson K, Jones B. The rock always comes first; drug users' accounts about using formal health care. Journal of Psychoactive Drugs. 2003; 35(4):461-469.

6. Merrill JO, Rhodes LA, Deyo RA, Marlatt GA, Bradley KA. Mutual mistrust in the medical care of drug users: the keys to the "narc" cabinet. J Gen Intern Med. 2002;17(5):327-333.

7. Neale J, Sheard L, Tompkins CN. Factors that help injecting drug users to access and benefit from services: A qualitative study. Subst Abuse Treat Prev Policy. 2007;2:31.

8. Palepu A, Tyndall MW, Leon $\mathrm{H}$, et al. Hospital utilization and costs in cohort of injection drug users. Canadian Medical Association Journal. 2001;165(4):415-420.

9. Wood E, Kerr T, Spittal PM, Tyndall MW, O'Shaughnessy MV, Schechter MT. The health care and fiscal costs of the illicit drug use epidemic: The impact of conventional drug control strategies, and the potential of a comprehensive approach. BC Medical Journal. 2003;45(3):128-134.

10. Paz-Bailey G, Raymond HF, Lansky A, Mermin J. Using the National HIV Behavioral Sur-veillance System to Inform HIV Prevention Efforts in the United States. AIDS Behav. 2014;18:S233-S236.

11. Centers for Disease Control and Prevention. Monitoring selected national HIV prevention and care objectives by using HIV surveillance data-United States and 6 dependent areas-2011. HIV Surveillance Supplemental Report. 2013 Oct;18(5). [updated 2013 Apr; cited 2014 Mar 30]. Available from:http://www.cdc.gov/hiv/pdf/2011_Monitoring_HIV_Indicators_ HSSR_FINAL.pdf.

12. Fleishman JA, Yehia BR, Moore RD, Korthuis PT, Gebo KA. Establishment, Retention, and Loss to Follow-Up in Outpatient HIV Care. J Acquir Immune Defic Syndr. 2012;60(3):249-259.

13. College of Physicians and Surgeons of Ontario. Avoiding Abuse, Achieving a Balance: Tackling the Opioid Public Health Crisis. 2010. 46 p. [updated 2013 Apr; cited 2014 Aug 1]. Available from: http://www.cpso.on.ca/CPSO/ media/uploadedfiles/policies/policies/Opioid_report_final.pdf

14. CBC News. Overdoses in Ottawa a preventable problem, say activists [Internet]. Ottawa (ON): CBC news; 2013 Aug 31[updated 2013 Aug 31; cited 2014 Mar 30]. Available from: http://www.cbc.ca/news/canada/ottawa/ overdoses-in-ottawa-a-preventable-problem-say-activists-1.1408951.

15. Gowing L, Farrell M, Bornemann R, Ali R. Substitution treatment of injecting opioid users for prevention of HIV infection. The Cochrane Database of Systematic Reviews. 2004;4:CD004145.

16. National Institute on Drug Abuse. Methadone maintenance treatment: Translating research into policy. Bethesda (MD) : National Institutes of Health, Public Health Services; 1995 Nov [cited 2014 Mar 30]. Available from: http://chodarr.org/sites/default/files/chodarr1448.pdf. 
17. Anderson MA, Boyd N. A cost-benefit and cost-effectiveness analysis of Vancouver's super-vised injection facility. International Journal of Drug Policy. 2010;21(1):70-76.

18. Pinkerton, SD. Is Vancouver Canada's supervised injection facility cost-saving? Addiction. 2010;105(8):1429-1436.

19. Dolan K, Kimber J, Fry C, Fitzgerald J, McDonald D, Trautmann F. Drug Consumption fa-cilities in Europe and the establishement of supervised injecting centers in Autralia. Drug and Alcohol review. 2000;19(3):337-346.

20. Salmon AM, Thein $\mathrm{H}-\mathrm{H}$, Kimber J, Kaldor JM, Maher L. Five years on: what are the com-munity perceptions of drug-related public amenity following the establishment of the Sydney

21. Medically Supervised Injecting Centre? International Journal of Drug Policy 2007;18(1):46-53.

22. Marshall BDL, Milloy M-J, Wood E, Montaner JSG, Kerr T. Reduction in overdose mortali-ty after the opening of North America's first medically supervised safer injecting facility: A ret-rospective population-based study. The Lancet. 2011;377(9775):1429-1437.

23. Ottawa Public Health. Overdose and HIV and hepatitis $C$ infection among people in Ottawa who use drugs. Ottawa (ON): City of Ottawa (CA) 2012 Jan. 12 p. [updated 2014 Jan; cited 2014 Aug 1] Available from: http://ottawa. ca/en/residents/public-health/health-statistics-and-reports/health-statusreports

24. Jozaghi E, Reid AA, Andresen MA, Juneau A. A cost-benefit/cost-effectiveness analysis of proposed supervised injection facilities in Ottawa, Canada. Substance Abuse Treatment, Preven-tion, and Policy. 2014;9:31. 